\title{
HUBUNGAN ANTARA KEMAMPUAN BERPIKIR KREATIF MATEMATIS DAN MOTIVASI BELAJAR SISWA SMP YANG MENGGUNAKAN PENDEKATAN CREATIVE PROBLEM SOLVING
}

\author{
Siti Eftafiyana1', Siti Asiyah Nurjanah², Marzan Armania³ , Asep Ikin Sugandi, \\ Nelly Fitriani ${ }^{5}$ \\ 1,2,3,4,5 Pendidikan Matematika Institut Keguruan dan IImu Pendidikan Siliwangi \\ Email : eftafiyana@gmail.com
}

Dikirim: 25 Januari 2018; Diterima: 25 Februari 2018; Dipublikasikan: 31 Maret 2018

\begin{abstract}
This research aimed to analyze how the correlation between the mathematic creatively thinking ability with students' learning motivation in learning using Creative Problem Solving (CPS) approach. The research method was quasi-experimental method, by taking two different classes, then first class got learning with CPS and second class used general learning approach. The population were all the students of junior highschool in Cimahi, with the sample took two classes. Both classes were given pretest in order to know their initial ability, then the experimental class was given a learning by CPS and the control class was given learning with the general method, and the last two classes were given post test and questionnaire about motivation learning wich data was processed and analyzed using Product Moment Person. The result showed a significant correlation between the mathematic creatively thinking ability with students' learning motivation in learning mathematic.
\end{abstract}

Keyword: Mathematic Creatively Thinking, Learning Motivation, Creative Problem Solving Approach.

\begin{abstract}
ABSTRAK
Penelitian ini bertjuan untuk menelaah bagaimana hubungan antara kemampuan berpikir kreatif matematis dengan motivasi belajar siswa dalam pembelajaran yang menggunakan pendekatan Creative Problem Solving (CPS). Metode penelitian yang digunakan adalah metode kuasi eksperimen, dengan cara mengambil dua kelas yang berbeda, kemudian kelas pertama mendapatkan pembelajaran dengan CPS dan kelas kedua menggunakan pembelajaran biasa. Populasinya adalah seluruh siswa SMP di Kota Cimahi, dengan sampel diambil dua kelas. Kedua kelas diberi pretes agar mengetahui kemampuan awal mereka, selanjutnya kelas eksperimen diberi pembelajaran dengan CPS dan kelas kontrol diberi pembeljaran biasa, dan terakhir kedua kelas diberikan postes dan angket motivasi belajar yang mana data tersebut akan diolah dan dianalisis korelasinya menggunakan Product Moment Person. Hasil penelitian menunjukan adanya hubungan yang signifikan antara kemampuan berpikir kretif matematis dan motivasi belajar siswa dalam pembelajaran matematika.
\end{abstract}

Kata kunci: Berpikir Kreatif Matematis, Motivasi Belajar , Pendekatan Creative Problem Solving

Cara sitasi: Eftafiyana, S., Nurjanah, S. A., Armania, M., Sugandi, A. I., dan Fitriani, N. 2018. Hubungan antara Kemampuan Berpikir Kreatif Matematis dan Motivasi Belajar Siswa SMP yang Menggunakan Pendekatan Creative Problem Solving. Teorema: Teori dan Riset Matematika Vol 2, No 2 (2018). Hal 85-92 


\section{PENDAHULUAN}

Matematika merupakan ratu ilmu dimana semua ilmu pengetahuan yang dipelajari pasti menggunakan matematika. Selain itu matematika merupakan ilmu dasar dalam perkembangan teknologi modern. Pada saat ini banyak siswa berpikir bahwa tujuan matematika adalah hanya untuk pintar berhitung. Ternyata lebih dari itu, matematika diajarkan pada dasarnya bertujuan untuk membantu melatih pola pikir siswa agar dapat memecahkan masalah dengan kreatif, kritis, logis dan tepat. Maka dari itu matematika sangat penting dan dipelajari pada tiap jenjang pendidikan, hal ini ditegaskan oleh Suherman (2003) menyatakan bahwa "Hal yang penting bagi siswa untuk bekal pengetahuan yang bertujuan membentuk sikap serta pola pikirnya adalah matematika yang dipelajari melalui pendidikan formal" .

Sejalan dengan hal yang telah dipaparkan sebelumnya, secara tidak langsung kurikulum 2013 menuntut siswa agar menemukan suatu konsep secara mandiri dengan harapan dapat mengembangkan kemampuan berpikir kreatif dengan cara memberikan pengalaman belajar. Maka salah satu aspek kognitif yang menjadi kebutuhan dan cukup penting dalam menunjang pembelajaran berbasis kurikulum 2013 salah satunya adalah kemampuan untuk berpikir kreatif. Siswono (2009) mengemukakan bahwa "kemampuan berpikir untuk menemukan banyak kemungkinan jawaban pada suatu masalah, dimana penekanannya pada kuantitas, ketepatgunaan dan keberagaman jawaban disebut sebagai kreativitas (berpikir kreatif atau divergen)". Maka hal tersebut menunjukan bahwa kemampuan berpikir seseorang akan makin tinggi jika ia mampu menunjukan dan menemukan banyak kemungkinan jawaban terhadap suatu masalah. Munandar (Hendriana dkk., 2017) menguraikan indikator berpikir kreatif secara rinci sebagai berikut: 1)Kelancaran (Fluency); 2)Kelenturan (Flexibelity); 3)Keaslian (Originality); 4)Elaborasi (Elaboration). Hal ini diperjelas oleh pendapat Munandar dan Silver (Santoso, 2016) menjelaskan bahwa kelancaran (fluency) mengacu pada kemampuan siswa dalam memberikan bermacam-macam jawaban, fleksibilitas (flexiblity) mengacu pada kemampuan siswa dalam menyelesaikan masalah tidak dengan satu cara tetapi bisa memberikan cara lain, keaslian (originality) mengacu pada kemampuan siswa melahirkan ungkapan baru dan unik, dan elaborasi (elaboration) mengacu pada kemampuan siswa untuk mampu memperkaya atau mengembangkann suatu gagasan.

Namun pada kenyataan di lapangan banyak siswa disetiap jenjang pendidikan yaitu dari sekolah dasar hingga perguruan tinggi menganggap bahwa matematika adalah pelajaran yang menyeramkan dan sulit untuk dikerjakan. Berdasarkan hasil wawancara pada siswa SMP lebih banyak siswa yang merasa kurangnya motivasi untuk belajar matematika, karena mereka berpandangan bahwa matematika merupakan pelajaran yang menakutkan yang dihantui oleh berbagai macam rumus. Patahnya semangat siswa dalam mengikuti pembelajaran matematika, dapat mempengaruhi pembelajaran yang diharapkan optimal dan faktanya siswa sering kali lupa bahwa belajar itu penting. Semakin maju perkembangan teknologi semakin turun motivasi untuk belajar siswa, hal ini disebabkan karena pengaruh dari lingkungan pergaulan serta teknologi yang semakin modern. Sehingga dampaknya terlihat dari rendahnya motivasi belajar dan kemampuan berpikir kreatif matematis siswa masih lemah. Ini ditunjukan oleh sebuah hasil penelitian internasional dalam bidang matematika dan sains Programe for Internasional Student Assesment (PISA) tahun 2012 (Iswadi, 2015) negara Indonesia menduduki peringkat 64 dari 65 negara. Demikian juga berdasarkan hasil The Trend Internasional Mathematics and Science Study (TIMSS) pada tahun 2011, Indonesia menduduki peringkat ke-38 dari 42 negara dengan nilai rata rata 386 . Soal-soal matematika yang tedapat pada TIMSS mengukur tingkat kemampuan siswa dalam memecahkan masalah yang sederhana sampai masalah yang membutuhkan kemampuan berpikir tingkat tinggi, sehingga karakteristik soal TIMSS menuntun siswa untuk dapat memiliki kemampuan berpikir kreatif, sehingga secara tidak langsung menujukkan kondisi siswa dalam berkemampuan kreatif.

Cara sitasi: Eftafiyana, S., Nurjanah, S. A., Armania, M., Sugandi, A. I., dan Fitriani, N. 2018. Hubungan antara Kemampuan Berpikir Kreatif Matematis dan Motivasi Belajar Siswa SMP yang Menggunakan Pendekatan Creative Problem Solving. Teorema: Teori dan Riset Matematika Vol 2, No 2 (2018). Hal 85-92 
Sebelumnya telah dijelaskan kurangnya kemampuan dalam aspek kognitif yaitu berpikir kreatif matematis diduga karena kurangnya pendorong untuk belajar atau bisa disebut kurangnya aspek afektif yaitu motivasi belajar. Oleh karena itu aspek kognitif yaitu kemampuan berpikir kreatif matematis itu penting, dan aspek afektif khususnya motivasi belajar juga penting. Selain karena yang telah dipaparkan sebelumnya, ini ditegaskan oleh Sardiman (2005) motivasi belajar merupakan unsur penting dalam belajar baik bagi siswa maupun guru, karena berfungsi untuk mendorong manusia dalam melakukan sesuatu, menentukan arah perbuatan, dan menyeleksi perbuatan mana yang harus dilakukan. Sejalan dengan itu, pendapat serupa dikemukakan oleh Hamzah (2008) pentingnya motivasi dalam matematika yaitu: a) Mencari hal-hal yang dijadikan sebagai penguat belajar, b) Menentukan atau mencari berbagai kendala terhadap rangsangan belajar; c) Memperjelas tujuan belajar yang hendak dicapainya; d) Menentukan atau mencari ketekunan belajar siswa , agar hasil belajar menjadi maksimal. Berdasarkan hal tersebut nampak bahwa motivasi belajar dalam belajar matematika itu cukup penting, karena motivasi belajar dapat mempengaruhi perbuatan siswa dalam mencapai tujuan yang diinginkan selain itu sebagai penggerak bagi siswa yaitu ketika proses belajar berlangsung yang dapat meningkatkan hasil belajar dan kemampuan berpikir kreatif matematis. Adapun indikator motivasi belajar menurut Sardiman (2005) meliputi: a) senang memecahkan soal dan mencari soal baru.; b) Cepat bosan dengan tugas-tugas rutin; c) Menunjukan minat untuk menyelesaikan bermacam-macam soal atau masalah; d) Lebih senang bekerja secara mandiri dibandingkan bekerja secara kelompok; e) Ulet dalam menghadapi kesulitan; f) Dapat mempertahankan pendapat yang dianggap benar; g) Tidak mudah melepaskan hal yang diyakini atau berpendirian teguh; h) Tekun dalam menghadapi tugas.

Permasalahan dalam pembelajaran matematika yang telah dipaparkan sebelumnya harus segera diatasi, salah satunya yaitu menjadi guru yang kreatif dan inovatif yang dapat membuat pembelajaran matematika menjadi menyenangkan, lebih menarik, tidak membosankan dan disukai oleh siswa. Selain itu dalam kegiatan belajar guru hanya sebagai motivator dan fasilitator, sedangkan pembelajaran harus berpusat pada siswa ini bertujuan agar suasana kelas menjadi hidup. Cara mengatasi ketidaksenangan siswa dalam meningkatkan motivasi belajar terhadap pembelajaran matematika yaitu dengan menggunakan pendekatan Creative Problem Solving (CPS) yang bertujuan agar siswa lebih terlatih untuk bertindak atas pemikiran secara kreatif. Pada pendekatan pembelajaran ini siswa diminta untuk berpikir secara kreatif untuk menemukan solusi dan cara penyelesaian terhadap masalah yang diajukan, selain itu diharapkan siswa bisa lebih termotivasi untuk belajar matematika.

Adapun langkah-langkah dari CPS menurut hasil penggabungan prosedur Von Oech dan Osborn (Pratiwi dkk, 2017), yaitu: (1) Klarifikasi masalah, yaitu siswa diberikan penjelasan mengenai masalah yang diajukan ini bertujuan agar siswa dapat memahami tentang penyelesaian yang diharapkan; (2) Pengungkapan gagasan, disini siswa mengungkapkan gagasan secara bebas mengenai berbagai macam strategi dalam penyelesaian masalah; (3) Evaluasi dan seleksi, disini Tiap kelompok mengemukakan strategi-strategi atau pendapat-pendapat yang cocok untuk dapat menyelesaikan masalah; dan (4) Implementasi, siswa dituntut untuk memilih strategi yang dapat digunakan untuk menyelesaikan masalah, setelah itu menerapkannya hingga dapat menemukan penyelesaian masalah. Berdasarkan langkah-langkah yang telah dipaparkan, diharapkan aspekaspek kemampuan matematika seperti, penggeneralisasian ,penemuan pola, penerapan aturan pada masalah tidak rutin, komunikasi matematika dapat dikembangkan.

Menurut Karen (Sumartono dkk, 2014), pendekatan Creative Problem Solving (CPS) adalah suatu pendekatan yang pembelajarannya berpusat pada keterampilan pemecahan masalah, diikuti dengan penguatan kreatifitas, yaitu ketika siswa dapat terampil untuk menentukan jawaban manakah yang cocok untuk memecahkan masalah yaitu mengembangkan dan memilih tanggapannya. Selain menghafal tanpa berpikir, keterampilan memecahkan masalah dalam

Cara sitasi: Eftafiyana, S., Nurjanah, S. A., Armania, M., Sugandi, A. I., dan Fitriani, N. 2018. Hubungan antara Kemampuan Berpikir Kreatif Matematis dan Motivasi Belajar Siswa SMP yang Menggunakan Pendekatan Creative Problem Solving. Teorema: Teori dan Riset Matematika Vol 2, No 2 (2018). Hal 85-92 
matematika dapat memperluas proses berpikir kreatif, dengan demikian pendekatan CPS ini diduga dapat meningkatkan kemampuan berpikir kreatif matematis dan motivasi belajar siswa.

Berdasarkan uraian yang telah dipaparkan, terdapat masalah yang cukup menarik untuk diteliti. Oleh sebab itu peneliti ingin menganalisis hubungan antara kemampuan berpikir kreatif matematis dan motivasi belajar siswa SMP yang menggunakan pendekatan creative problem solving.

\section{METODE PENELITIAN}

Penelitian ini menggunakan metode kuasi eksperimen, dimana populasinya adalah seluruh siswa SMP pada salah satu sekolah di Kota Cimahi, dan diambil sampel dua buah kelas, kelas pertama (eksperimen) menggunakan pendekatan Creative Problem Solving dan kelas kedua (kontrol) menggunakan pembelajaran biasa.

Instrumen kemampuan berpikir kreatif matematis dan angket motivasi belajar digunakan untuk intrumen penelitian ini. Skor Angket kemudian ditransformasikan menggunakan Method of Sucsesive Interval (MSI), kemudian di uji korelasi menggunakan Product Moment Pearson.

\section{HASIL DAN PEMBAHASAN}

Hipotesis dalam penelitian ini yaitu "Terdapat hubungan yang positif antara kemampuan berpikir kreatif matematis dan motivasi belajar siswa SMP dalam pembelajaran menggunakan pendekatan Creative Problem Solving".Sebagai prasyarat dilakukan uji normalitas, jika data berdistribusi normal selanjutnya dilakukan uji korelasi Product Moment Pearson dan sebaliknya jika data tidak berdistribusi normal maka di uji korelasi Spearmant. Uji korelasi dibutuhkan untuk menguji hipotesis tersebut.

a. Uji Normalitas Data Kelas Kontrol

Hipotesis yang akan diuji :

$\mathrm{H}_{0}$ : Data kemampuan berpikir kreatif matematis dan motivasi belajar kelas kontrol berdistribusi normal.

$\mathrm{H}_{1}$ : Data kemampuan berpikir kreatif matematis dan motivasi belajar kelas kontrol tidak berdistribusi normal.

Tabel 1. Hasil Uji Normalitas Data Skor Berpikir Kreatif Matematis dan Motivasi Belajar Kelas dengan Pembelajaran Biasa (Kontrol)

\begin{tabular}{ccccccc} 
& \multicolumn{3}{c}{ Kolmogorov-Smirnova } & \multicolumn{3}{c}{ Shapiro-Wilk } \\
\cline { 2 - 7 } & Statistic & Df & Sig. & Statistic & df & Sig. \\
\hline tes_kelas_kontrol & 0,126 & 34 & 0,189 & 0,955 & 34 & 0,177 \\
\hline angket_kelas_kontrol & 0,150 & 34 & 0,051 & 0,898 & 34 & 0,044 \\
\hline
\end{tabular}

Kriteria pengambilan uji normalitas adalah sebagai berikut :

1) Jika nilai signifikasi lebiih kecil dari 0,05 maka $\mathrm{H}_{0}$ ditolak

2) Jika nilai signifikasi lebiih besar sama dengan 0,05 maka $H_{0}$ diterima

Berdasarkan Tabel 1, ternyata nilai Signifikansi uji Kolmogorov Smirnov pada skor postes kemampuan berpikir kreatif matematis kelas kontrol menunjukan nilai $0,189 \geq 0,05$, begitu juga untuk skor motivasi belajar siswa kelas kontrol yaitu $0,051 \geq 0,05$, maka $\mathrm{H}_{0}$ diterima. Ini berarti data postes kemampuan berpikir kreatif matematis dan motivasi belajar siswa yang menggunakan pembelajaran biasa berdistribusi normal.

Cara sitasi: Eftafiyana, S., Nurjanah, S. A., Armania, M., Sugandi, A. I., dan Fitriani, N. 2018. Hubungan antara Kemampuan Berpikir Kreatif Matematis dan Motivasi Belajar Siswa SMP yang Menggunakan Pendekatan Creative Problem Solving. Teorema: Teori dan Riset Matematika Vol 2, No 2 (2018). Hal 85-92 
b. Uji Normalitas Data Kelas Eksperimen Hipotesis yang akan diuji :

$\mathrm{H}_{\mathrm{o}}$ : Data kemampuan berpikir kreatif matematis dan motivasi belajar kelas kontrol berdistribusi normal.

$\mathrm{H}_{1}$ : Data kemampuan berpikir kreatif matematis dan motivasi belajar kelas kontrol tidak berdistribusi normal.

Tabel 2. Hasil Uji Normalitas Data Skor Berpikir Kreatif Matematis dan Motivasi Belajar Kelas Eksperimen

\begin{tabular}{ccccccc} 
& \multicolumn{3}{c}{ Kolmogorov-Smirnova } & \multicolumn{3}{c}{ Shapiro-Wilk } \\
\cline { 2 - 7 } & Statistic & Df & Sig. & Statistic & df & Sig. \\
\hline tes_kelas_eksperimen & 0,133 & 34 & 0,135 & 0,950 & 34 & 0,122 \\
\hline angket_kelas_eksperimen & 0,133 & 34 & 0,200 & 0,901 & 34 & 0,005 \\
\hline
\end{tabular}

Kriteria pengambilan uji normalitas adalah sebagaiberikut :

1) Jika nilai signifikasi lebiih kecil dari 0,05 maka $\mathrm{H}_{0}$ ditolak

2) Jika nilai signifikasi lebiih besar sama dengan 0,05 maka $\mathrm{H}_{0}$ diterima

Dari Tabel 2 di atas, ternyata nilai Signifikansi uji Kolmogorov Smirnov pada skor postes kemampuan berpikir kreatif matematis kelas eksperimen menunjukan nilai $0,135 \geq 0,05$, begitu juga skor motivasi belajar siswa kelas eksperimen yaitu $0,200 \geq 0,05$, maka $\mathrm{H}_{0}$ diterima. Ini berarti data postes kemampuan berpikir kreatif matematis dan motivasi belajar siswa pada kelas eksperimen berdistribusi normal.

c. Uji Korelasi Kemampuan Berpikir Kreatif Matematis dan Motivasi Belajar Siswa dalam Matematika

Dari data yang telah dihitung sebelumnya telah diketahui bahwa baik kelas kontrol maupun kelas eksperimen berdistribusi normal. Uji korelasi Product Moment Pearson dengan taraf signifikansi 0,05 digunakan untuk mengetahui seberapa kuat hubungan antara kemampuan berpikir kreatif matematis dan motivasi belajar siswa dalam matematik digunakan.

1. Kelas Kontrol

Berikut hipotesis yang digunakan untuk menguji hipotesis penelitian sebelumnya.

$\mathrm{H}_{\mathrm{o}}$ : tidak terdapat hubungan yang signifikan antara kemampuan berpikir kreatif matematis dengan motivasi belajar siswa kelas kontrol.

$\mathrm{H}_{1}$ : terdapat hubungan yang signifikan antara kemampuan berpikir kreatif matematis dengan motivasi belajar siswa kelas kontrol.

Kriteria pengujian yang digunakan adalah:

1) jika signifikansi nilainya lebih besar sama dengan 0,05 maka $\mathrm{H}_{0}$ diterima

2) jika signifikansi nilainya lebih kecil dari 0,05 maka $\mathrm{H}_{0}$ ditolak

Hasil pengelolaan korelasi ditunjukan pada tabel berikut:

Cara sitasi: Eftafiyana, S., Nurjanah, S. A., Armania, M., Sugandi, A. I., dan Fitriani, N. 2018. Hubungan antara Kemampuan Berpikir Kreatif Matematis dan Motivasi Belajar Siswa SMP yang Menggunakan Pendekatan Creative Problem Solving. Teorema: Teori dan Riset Matematika Vol 2, No 2 (2018). Hal 85-92 
Tabel 3. Hasil Uji Korelasi antara Kemampuan Berpikir Kreatif Matematis dan Motivasi Belajar Siswa Kelas Kontrol

\begin{tabular}{llrr}
\hline & & tes_kelas_kontrol & angket_kelas_kontrol \\
\hline tes_kelas_kontrol & Pearson Correlation & 1 & $0,438^{\star *}$ \\
& Sig. (2-tailed) & & 0,004 \\
& $N$ & $0,438^{* *}$ & 34 \\
\hline angket_kelas_kontrol & Pearson Correlation & 0,004 & 1 \\
& Sig. (2-tailed) & 34 & 34 \\
& $\mathrm{~N}$ & 34 & 34 \\
\hline
\end{tabular}

Dari Tabel 3 di atas, ternyata nilai hasil korelasi antar kemampuan berpikir kreatif matematis dan motivasi belajar siswa kontrol sebesar 0,483 dan nilai signifikansi sebesar 0,004. Harga korelasi ( $r$ ) yang diperoleh adalah 0,483 yang artinya tingkat hubungannya cukup. Karena nilai signifikansinya 0,004 kurang dari 0,05 maka terdapat hubungan yang signifikan antara kemampuan berpikir kreatif matematis dan motivasi belajar kelas kontrol.

2. Kelas Eksperimen

Berikut adalah hipotesis yang digunakan untuk menguji hipotesis dalam penelitian ini:

$\mathrm{H}_{0}$ : tidak terdapat hubungan yang signifikan antara kemampuan berpikir kreatif matematis dan motivasi belajar siswa kelas eksperimen

$\mathrm{H}_{1}$ : terdapat hubungan yang signifikan antara kemampuan berpikir kreatif matematis dan motivasi belajar siswa kelas eksperimen

Kriteria pengujian yang digunakan adalah:

1) Jika signifikansi nilainya lebih besar dari 0,05 maka $\mathrm{H}_{0}$ diterima

2) Jika signifikansi nilainya lebih kecil dari 0,05 maka $\mathrm{H}_{0}$ ditolak

Hasil pengolahan korelasi ditunjukan pada tabel berikut:

Tabel 4. Hasil Uji Korelasi antara Kemampuan Berpikir Kreatif Matematis dan Motivasi Belajar Siswa Kelas Eksperimen

\begin{tabular}{llrr}
\hline & Pearson Correlation & $\begin{array}{c}\text { tes_kelas } \\
\text { _eksperimen }\end{array}$ & $\begin{array}{r}\text { angket_kelas } \\
\text { _eksperimen }\end{array}$ \\
\hline tes_kelas_eksperimen & Sig. (2-tailed) & 34 & $0,621^{\text {** }}$ \\
& $\mathrm{N}$ & 0,000 \\
angket_kelas_eksperimen & Pearson Correlation & $0,621^{* *}$ & 34 \\
& Sig. (2-tailed) & 0,000 & 1 \\
& $\mathrm{~N}$ & 34 & 34 \\
\hline
\end{tabular}

Berdasarkan Tabel 4, ternyata nilai hasil korelasi antara kemampuan berpikir kreatif matematis dan motivasi belajar siswa dalam kelas eksperimen adalah 0,621 dan nilai signifikansi sebesar 0,000 . Sedangkan harga korelasi $(r)$ yang diperoleh adalah 0,621 yang artinya tingkat hubungan kuat. Karena nilai signifikan 0,000 kurang dari 0,05 maka terdapat hubungan yang signifikan antara kemampuan berpikir kreatif matematis dan motivasi belajar kelas eksperimen.

Pada kedua kelas, baik kelas kontrol (pembelajarannya biasa) maupun kelas eksperimen (pembelajaran menggunakan pendekatan Creative Problem Solving) terjadi hubungan yang berbeda, antara kemampuan berpikir kreatif matematik dan motivasi belajar yang dimiliki oleh siswa. Namun bedanya, apabila pada kelas eksperimen, hasil postes angket

Cara sitasi: Eftafiyana, S., Nurjanah, S. A., Armania, M., Sugandi, A. I., dan Fitriani, N. 2018. Hubungan antara Kemampuan Berpikir Kreatif Matematis dan Motivasi Belajar Siswa SMP yang Menggunakan Pendekatan Creative Problem Solving. Teorema: Teori dan Riset Matematika Vol 2, No 2 (2018). Hal 85-92 
yang diberikan setelah pembelajaran dengan menggunakan pendekatan Creative Problem Solving terlihat di atas rata-rata dari hasil postes dan angket akhir siswa yang menggunakan pembelajaran biasa. Artinya pada kelas eksperimen terjadi semakin tinggi kemampuan berpikir kreatif matematis siswa maka akan semakin tinggi juga motivasi belajar yang dimiliki siswa. Bedanya dengan kelas kontrol, jika kemampuan berpikir kreatif matematik yang dimiliki siswa kurang, maka demikian pula dengan motivasi yang dimiliki oleh siswa.

Berdasarkan hasil analisis yang telah dipaparkan, dapat kita tarik kesimpulan bahwa pembelajaran matematika dengan menggunakan pendekatan Creative Problem Solving akan meningkatkan kemampuan berpikir kreatif matematis siswa, dan juga berdampak langsung pada peningkatan motivasi belajar yang dimilki oleh siswa.

\section{KESIMPULAN}

Kesimpulan pada penelitian ini adalah terdapat hubungan yang positif dan signifikan antara kemampuan berpikir kreatif matematis dan motivasi belajar baik pada siswa yang mendapatkan pembelajaran biasa maupun siswa yang mendapatkan pembelajaran menggunakan pendekatan Creative Problem Solving.

\section{REKOMENDASI}

Berdasarkan kesimpulan yang telah dipaparkan, maka penulis mengajukan rekomendasi yang dipandang berguna dan dapat dipertimbangkan agar mampu meningkatkan kemampuan matematis dan motivasi belajar siswa SMP :

1. Peneliti selanjutnya agar dapat meneliti motivasi belajar terkait dengan kemampuan matematis lain, atau kemampuan berpikir kreatif matematis dengan aspek psikologi lain.

2. Guru matematika, agar dapat melakukan pembelajaran dengan menggunakan pendekatan Creative Problem Solving untuk meneliti hubungan kemampuan berpikir matematis dengan aspek psikologi lainnya.

\section{UCAPAN TERIMAKASIH}

Penulis mengucapkan terimakasih kepada Dr.Asep Ikin Sugandi, M.Pd. dan Nelly Fitriani, M.Pd. karena dukungan dan bimbingannya dalam menyelesaikan penelitian ini.

\section{DAFTAR PUSTAKA}

Hamzah. B. (2008). Teori Motivasi dan Pengukuranya, Analisis di Bidang Pendidikan. Jakarta: Bumi Aksara.

Hendriana, H., Rohaeti, E.,E., Sumarmo, U. (2017). Hard Skills dan Soft Skills. Bandung: Aditama.

Iswadi, H.(2015). Sekelumit Hasil PISA 2015 yang Baru Rilis. [Online] tersedia : http://www.ubaya.ac.id/2014/content/articles_detail/230/Overview-of-the-PISA-2015results-that-have-just-been-Released.html. [ 15 Oktober 2017].

Pratiwi E. M., Kriwandari, Prihatnani E., (2017). Pengaruh Model Pembelajaran Creative Problem Solving terhadap Minat Belajar dan Hasil Belajar Siswa Kelas IX SMP N 2 Tuntang. Jurnal Universitas Kristen Sattya Wacana., 20(2). :92-106.

Santoso, H.R.W., Ratu, N., Yunianta T.N.H., (2016). Deskripsi Tingkat Kemampuan Berpikir Kreatif (Tkbk) Pada Materi Segiempat Siswa Kelas VII Smp Negeri 1 Pabelan Kabupaten Semarang.Jurnal Universitas Kristen Sattya Wacana., 30(2). :82-95.

Cara sitasi: Eftafiyana, S., Nurjanah, S. A., Armania, M., Sugandi, A. I., dan Fitriani, N. 2018. Hubungan antara Kemampuan Berpikir Kreatif Matematis dan Motivasi Belajar Siswa SMP yang Menggunakan Pendekatan Creative Problem Solving. Teorema: Teori dan Riset Matematika Vol 2, No 2 (2018). Hal 85-92 
Sardiman, A.M. (2005). Interaksi dan Motivasi Belajar Mengajar. Jakarta :Rajawali Press.

Siswono, T.Y.E.(2009). Meningkatkan Kemampuan Berpikir Kreatif Siswa Melalui Pemecahan Masalah Tipe "What's Another Way". Jurnal Pendidikan Matematika "transformasi". 19(1): $(1-13)$.

Sumartono, Yustari E., (2014). Penerapan Model Pembelajaran Creative Problem Solving (CPS) dalam Pembelajaran Matematika di Kelas VIII SMP. Jurnal Pendidikan Matematika., 2(3): 187-193.

Suherman, E. (2003). Strategi Pembelajaran Matematika Kotemporer. Bandung: JICA-IMSTEP Universitas Pendidikan Indonesia. 